\title{
The Role of Institutional-Legal Capacity and Power in Explaining the Performance of Developing Countries in WTO Disputes against the G2
}

\author{
Maria Izabel V de Carvalho* \\ Carlos Henrique Canesin**
}

\begin{abstract}
This article analyses the performance of developing countries in WTO disputes against the USA and EU (the G2) from 1995 to 2012. It investigates the influence of four factors - WTO rules and norms, institutional-legal capacity, market power, and trade dynamics - on two samples, namely disputes initiated and successfully concluded against the G2. Generalized Linear Models (GLMs) are used to analyse the data. They show that, while relative bilateral exports also play a role, the institutional-legal capacity and market power of developing countries (as represented by GDP) play the most important role in allowing developing countries to initiate disputes against the G2, and to complete them successully.
\end{abstract}

Keywords: Developing countries and WTO disputes; WTO dispute settlement system; market power; Generalized Linear Model; institutional-legal capacity.

\section{Introduction}

In 2001, the Brazilian Association of Cotton Producers (ABRAPA) asked the Brazilian Ministry of Foreign Affairs (MRE) to initiate a dispute at the WTO against US domestic subsidies that favoured American producers and undermined Brazilian ones in the international cotton trade.

The then head of the MRE Coordination of Litigation (and current Director-General of the WTO), Roberto Azevêdo, stressed the unprecedented nature of the dispute and a resultant need for caution, stating that the cotton case would be the 'first to question domestic agricultural subsidies at the WTO; the first to raise the issues of the Peace Clause and the Green Box; [and] the first dispute about export credits for agricultural products'

\footnotetext{
* University of Brasilia (UnB), Brasília-DF, Brazil; mabel@unb.br. ORCID iD 0000-0001-8503-3554.

** University of Brasilia (UnB) and Brazilian Agricultural Research Corporation (Embrapa), Brasília-DF, Brazil; carlos.canesin@embrapa.br. OCRCID iD 0000-0001-6956-7548.
} 
(Costa and Bueno 2004, quoted in Habka 2013: 134, translated by the authors). Azevêdo pointed to the strategic implications of an adverse finding: 'If we lose, we would be legitimising US agricultural policy, as the USA could say, "You are complaining about our subsidies, but the WTO has found that our farm bill has no problem, so we don't have to change anything' (Costa and Bueno 2004, quoted in Habka 2013: 91, translated by the authors). He also expressed concerns about the costs of pursuing the dispute, including the costs of preliminary economic and legal analyses and of the proceedings themselves, and stated that without the financial support of ABRAPA, the Brazilian government could not carry them on its own. The eventual decision to declare a dispute was only taken after ABRAPA assured the MRE that it would carry the costs of pursuing the dispute at the WTO (Habka 2013: 134).

This points to some of the difficulties facing developing countries in initiating WTO disputes against the USA and EU, deriving from differences in legal-institutional capabilities, market power, and trade performance. As in the Brazilian cotton case, they include the ability to obtain and process information about the commercial damage suffered; analyse legal, political and economic implications; mobilise the resources needed to take the litigation forward; and deal with possible economic and political pressures throughout the dispute process.

This study addresses these issues by analysing the performance of selected developing countries in disputes against the USA and the EU (G2). ${ }^{1}$ Two separate but complementary data sets were utilised. The first comprises all the cases initiated against the G2 by developing countries. This makes it possible to examine the relationship between the absolute number of cases and the proposed explanatory variables. The second comprises only cases concluded in the period under review with favourable and non-favourable outcomes for developing countries. This enables an examination of the relationship between the absolute number of positive results, the success rate of each country, and the potential explanatory variables. The research covers the period from 1 January 1995, when the WTO came into force, to 31 December 2012 (WTO 2015, 2016a).

The WTO's dispute settlement system is governed by its Understanding on Rules and Procedures Governing the Settlement of Disputes, or Dispute Settlement Understanding (DSU), which came into effect on 1 January 1995 along with the WTO. In brief, a dispute arises when one country adopts a trade policy measure or takes some action that one or more fellow WTO members considers to be breaking the WTO agreements, or amounts to a failure to live up to its obligations. A third group of countries can declare that they have an interest in the case, and enjoy some rights.

Disputes are settled by the Dispute Settlement Body (DSB), the General Council in another guise, which consists of all WTO members (WTO 2016c). It has the authority to establish panels of experts to consider the case, and to accept or reject the panels' findings or the results of an appeal. It monitors the implementation of the rulings and recommendations, and has the power to authorise retaliation when a country does not comply with a ruling. 
While much of the procedure resembles a court or tribunal, the preferred solution is for the countries concerned to reach a negotiated settlement. Therefore, the first stage comprises consultations between the governments concerned. Even when the case has progressed to other stages, consultation and mediation remain possible. During the consultation stage, the countries in dispute are seek to reach a negotiated settlement. They can also ask the WTO director-general to mediate or assist in any other ways. If consultations fail, the complaining country can ask for the appointment of a panel of experts, which makes a proposed ruling. The panel's report is passed onto the Dispute Settlement Body, which can only reject the report by consensus. Both sides can appeal against the report. Appeals are heard by a permanent Appellate Body, which can uphold, modify or reverse the panel's findings and conclusions.

In the period under review, developing countries initiated 190 disputes. Of these, more than half (106, or 57\%) were lodged against the G2; 9\% (17) against developed countries; and 35\% (67) against other developing countries. The data points to the existence of two relevant markets for developing countries: the G2, which combined is the world's largest market; and large developing countries, such as China, India and Brazil. This study focuses on disputes lodged against the G2 and concluded in the period in question. Of 106 cases initiated against the G2, 29 remained in the initial consultation period, and 27 had not been concluded. A total of 50 cases were concluded, $86 \%$ in favour of developing countries, and $14 \%$ in favour of the G2.

Twenty-two countries started consultations, and 18 concluded disputes. The first group includes Argentina, Antigua and Barbuda, Brazil, China, Chile, Colombia, Costa Rica, Dominican Republic, Ecuador, Guatemala, Honduras, Indonesia, India, Mexico, Malaysia, Panama, Pakistan, Peru, Slovenia, Thailand, Venezuela, and Vietnam. He second group includes Argentina, Brazil, China, Chile, Colombia, Costa Rica, Ecuador, Guatemala, Honduras, India, Indonesia, Mexico, Malaysia, Panama, Pakistan, Peru, Thailand, and Venezuela.

The literature is equivocal about the effects of the WTO rules on disputes declared by developing countries, especially against the G2. Some studies show that the rule of reverse consensus and regulations for the suspension of concessions and/or obligations provide developing countries with important advantages. Others show that the same rules may have negative consequences for poor countries and/or small economies with low levels of economic growth.

Research has not produced definitive findings about the effects of market power and institutional-legal capacity. This study focuses on two factors, namely institutional-legal capability and market power. It responds to three research questions regarding our group of developing countries:

i. Do differences in institutional and legal capacity, market power, and trade dynamics of developing countries affect the likelihood of developing countries lodging complaints at the WTO against the G2?

ii. If this is the case, do these factors also affect the likelihood of developing countries achieving success in the litigation stage? 
iii. Do other differences in levels of development have significant impacts on the initiation and completion of disputes?

The first section of this article discusses issues surrounding the DSU. The second section discusses various theoretical perspectives on factors influencing the performance of members in the WTO dispute settlement system. The third section examines the decisionmaking procedures of the WTO dispute settlement system, and the significance of its findings in respect of developing countries. The fourth section presents the research and analyses the results.

\section{The DSU and developing countries}

This section discusses the issues surrounding the rules and procedures embodied in the DSU (WTO 2016b) which are relevant to the disputes declared by developing countries. It argues that although rules are important for broadening the capacity of developing countries to participate in the WTO dispute settlement system, they also have negative side-effects.

The GATT/WTO dispute settlement system has been repeatedly reformed in an attempt to reduce the influence of the interests of individual member states, notably those of more powerful members (Jackson 2008: 441-445). Until 1955, GATT member states participated directly in the resolution of disputes. In 1955, a panel of experts was introduced, but its members were still appointed by member states. In 1962, it was decided that any offence in relation to GATT rules would be regarded as 'prima facie nullification or impairment' (Jackson 2008: 442). In this way, the burden of proof was placed on the infringing party. This was an important step towards establishing a more legalised process because it 'reinforced a shift in the focus of GATT cases towards the treaty obligations imposed by the GATT, that is, in the direction of rule orientation' (Jackson 2008: 443). From the late 1970s onwards, panel recommendations were increasingly submitted to the GATT Council, comprising representatives of member states, for approval or rejection, in line with the principle of positive consensus. This allowed panel verdicts to be blocked by respondent members which were not satisfied with the outcomes. Dissatisfaction with this process led to the establishment of a new set of rules for managing disputes during the Uruguay Round.

As noted by Jackson (2008), the new dispute resolution mechanism was extended to apply to all areas negotiated under GATT/WTO; prevented respondent members from blocking disputes; introduced the reverse consensus rule for the approval of panel results by the Council, thereby preventing the losing party from paralysing the process; and created an appeal system (the Appellate Body), which replaced some of the previous functions of the Council. The last-named step reinforced the legalisation of the dispute resolution process by introducing an expert body to evaluate panel findings. In the process, the dispute settlement system became far more complex. As set out in Article 3.2 of the DSU, it not only seeks to enforce the rights and obligations of members according to WTO 
agreements, but also 'to clarify the existing provisions of those agreements in accordance with customary rules of interpretation of public international law'.

As evidenced by the existence of the Advisory Centre on WTO Law (ACWL), dispute settlement decisions are based on extensive legal documentation, covering 20 agreements. If all tariff tables and commitments of members are taken into account, it would reach more than 20000 pages and more than 300 documents, including the General Agreement on Tariffs and Trade of 1947 (GATT), all the decisions by Contracting Parties to the GATT, and all the jurisprudence of the adjudicative bodies of the GATT and the WTO (ACWL 2016). The extent and complexity of data accumulated during 45 years of the GATT and 27 years of the WTO present developing countries with major challenges, creating significant difficulties for countries with more limited economic resources.

Another important change in the GATT dispute settlement system involved the suspension of concessions and obligations. This allowed the complainant to seek permission to suspend its concessions and obligations towards the respondent, should the latter fail to implement decisions of the panel and Appellate Body within the required period. The suspension of concessions and/or obligations and the establishment of compensation measures are temporary, and do not replace 'full implementation of a recommendation to bring a measure into conformity with the covered agreements' (WTO 2016a: Art. 22.1).

Some developing countries have started to use the threat of cross-retaliation with positive results in disputes against developed countries. The first country to do so was Ecuador, in the case of the EU regime for the import of bananas. Brazil also recently used this mechanism to break a deal with the USA with respect to cotton.

The suspension of concessions and obligations is controversial, as it also affects consumers in the complainant country. By 2016, only six retaliatory steps had been taken, and none by developing countries (WTO 2016a).

It thus appears that the WTO rules have different consequences for different members in developing disputes against the USA and EU. On the one hand, the reverse consensus rule and the suspension of concessions and obligations are embedded in a context of 'legal framing' (Davis 2006). This is a context in which conflicts are decided under general rules adopted by all members, and potentially allow disputes to be resolved impartially. On the other, these rules may have negative consequences for developing countries in that they require extensive knowledge of WTO law and jurisprudence as well as institutions. Moreover, it is often difficult for countries with smaller economies to apply sanctions against larger ones.

\section{Rules, capabilities, and trade dynamics: constraints on disputes by developing country members}

This section reviews the major findings of studies of the performance of developing countries in WTO disputes. These studies incorporate three perspectives: i) an institutionalist perspective, which focuses on rules and procedures; ii) a political perspective, which fo- 
cuses on the relationships derived from relative power and capacity; and iii) an economic perspective, which emphases the role of trade dynamics in WTO disputes.

The institutionalist perspective holds that that rules and norms help to reduce and even eliminate the effects of power differences on how trade disputes are resolved. However, it appears that the DSU rules and norms do not succeed in eliminating the effects of differences in market power, the ability to retaliate, institutional and legal capacity, and economic resources. This affects the likelihood of developing countries declaring and sustaining disputes against the G2. In this view, the DSU constrains the conduct of member states; reduces opportunistic behaviour by the most powerful states; subjects all members to the same agreed regulations; ensures that independent third parties may be invoked to resolve trade disputes; enables powerful countries to be brought to trial; and allows their trade policies to be corrected to conform to WTO canons.

Investigating the evolution of the GATT dispute settlement system up to the establishment of the WTO, Jackson (2009) argues that several institutional changes reduced the influence of the interests of member states, especially the most powerful ones, on the dispute settlement system, and helped to improve the performance of developing countries. Case studies by Davis (2006) and Smith (2006) also place the DSU in a positive light.

In situations where 'the negotiation occurs within the bounds of formal rules and appeals to third party mediation' (Davis 2006: 222), the powerful country can be brought to trial; its trade policies can be questioned; the damage caused by them can be repaired; and the trade devices in question can be revised. In the absence of rules for regulating commercial disputes, developing countries are at the mercy of the interests of the most powerful countries. Davis (2006) compared the resolution of trade disputes between Vietnam and the USA when the former was a WTO member, and between Peru and the EU, when the former was already a member. Although the USA and Vietnam had a broad bilateral trade agreement, this did not allow for disputes to be mediated by a third party. As a result, Vietnam found it very difficult to force the USA to resolve trade disputes. Moreover, the damage inflicted on Vietnamese trade by USA policies was not satisfactorily repaired. The dispute between Peru and the EU about the imposition of technical barriers on Peru sardine exports had a different outcome. WTO rules led not only to Peru's losses being repaired, but also to the rules being reinforced (DS231 European Communities - Trade Description of Sardines).

Even China, a powerful developing country, faced problems in resolving trade disputes with developed countries, especially the USA, before joining the WTO. Disputes 'often resulted in the application of unilateral measures against China that would otherwise have been inconsistent with multilateral rules' (Liyu and Gao 2011: 141).

Following a study of the dispute between Ecuador and the EU over the latter's banana import regime, which asymmetrically benefited its former colonies, Smith (2006: 265279) points out that DSU rules can also be used by developing countries to enforce the implementation of panel results. During the panel phase, Ecuador adopted the same stance as the other complaining countries, namely Colombia, Guatemala, Honduras, Mexico, led by the USA. Later, however, Ecuador took a different route from the USA. While the 
USA applied sanctions against the EU, Ecuador demanded a compliance panel. The panel found that the EU had not complied with the finding of the first panel and the Appellate Body. Ecuador then claimed and acquired, for the first time in WTO history, the prerogative to use cross-retaliation, targeting intellectual property rights. This brought the EU back to the negotiating table, and allowed Ecuador to secure a more favourable outcome.

While the institutionalist perspective emphasises the relevance of rules and norms in relation to the interests of countries, the political perspective emphasises the relative ability and power of states to utilise these rules and avoid and/or bend them. We will examine two of these factors: institutional-legal capacity, and market power.

Busch, Reinhardt and Shaffer (2008: 10) have defined market power as 'the ability of one state to shift the terms of trade in its favour by imposing trade restrictions. Therefore, the market power of a given country is related to the size of its domestic market and the role played by trade, both regular and preferential trade. Therefore, it points to differences in relative power among countries, the power to repeal and/or resist threats of economic retaliation, and the suspension of obligations and concessions (WTO 2016a). Several studies have concluded that countries with greater market power are more likely to file WTO complaints (Bown 2005), and are more able to deter their partners from restricting trade (Blonigen and Bown 2003; Busch, Raciborski and Reinhardt 2007, cited in Busch, Reinhardt and Shaffer 2008: 10).

Guzman and Simmons (2005), however, argue that the relationship between complainants and respondents is not determined by differences in power, but by differences in their institutional-legal capacities. They focus on bilateral pair (complainant-respondent) cases initiated between 1995 and 2004. They depart from the assumption that WTO members only undertake disputes when the potential benefits outweigh the foreseen costs. According to these authors, countries evaluate two types of costs before lodging a dispute: i) capacity costs, related to the financial, institutional and human resources need to pursue a complaint; and ii) power costs, related to other steps the respondent state might in retaliation for having a dispute declared against them. According to the authors, 'These costs are more easily borne if the [complainant] state has greater capacity' (Guzman and Simmons 2005: 7).

These scholars argue that differences in the performance of countries are better explained in terms of differences in institutional-legal capacities than relative power. One interesting finding is that countries with limited capabilities tend to initiate cases that allow them to obtain higher gains. Consequently, they tend to declare disputes against countries with large markets, despite significant differences in relative power. This is because developing countries tend to have less institutional-legal capability for managing multiple disputes. As a result, they focus on a few most promising ones.

Institutional-legal capability can be defined as 'the institutional, financial, and human resources available to pursue a case' (Guzman and Simmons 2005: 7). The effective use of the advantages brought by the DSU rules depends on the availability of appropriate level of financial, organisational and human resources. It is more difficult for developing and least developed WTO member states than for developed member states to mobilise these 
sorts of resources (Francois, Horn and Kanitz 2008; Busch, Reinhardt and Shaffer 2008, 2009; Bown and Mcculloch 2010; Shaffer and Meléndez-Ortiz 2011). Identifying and processing all the relevant information is the main obstacle faced by developing countries in initiating disputes (Bown and Mcculloch 2010). They need to verify and demonstrate the damage suffered, and establish the link between those damages and a specific infringement of WTO rules.

A frequent problem raised in the literature is how these capabilities should be measured. Francois, Horn and Kanitz (2008: 20-21) argue that GDP per capita does not account for the reality of some developing countries: '[f] or instance, certain countries have a highly educated elite, with excellent knowledge of WTO law, while at the same time having very low per capita income. India is an obvious example.' As a result, they propose that GDP should only be used as a 'proxy of the absolute amount of legal capacity of a country'.

Their study uses data from 351 cases in the period of 1 January 1995 to 31 December 2006. They also use trade indicators, such as trade volume and composition. They find that aggregate levels of dispute initiation are fairly well explained by composition of trade, volume of trade, income levels, aid levels, and legal capacity (Francois, Horn and Kanitz 2008: 1).

Busch, Reinhardt and Shaffer $(2008,2009)$ agree with Francois, Horn and Kaunitz (2008) that per capita income is not a valid indicator of institutional-legal capability. They advance the discussion by creating an index with direct indicators instead of proxies. Their index contains the following indicators: whether countries have specialised divisions in WTO litigation, with some staff based in Geneva; the staff allocated to them; their experience of WTO matters; the degree to which states depend on the replacement of staff on mission in Geneva and in their domestic bureaucracies; and the level of coordination between governments and private firms. This index was used to research 1300 anti-dumping cases in 17 countries. Controlling for market power, the authors conclude that members with greater institutional-legal capacities file proportionally more complaints against anti-dumping measures imposed on their firms by other countries; and that these countries are also less subject to anti-dumping measures initiated by other countries. They also find that 'legal capacity affects patterns of dispute initiation and underlying antidumping protection among WTO members at least as much as market power, if not more' (2008: 14).

Thus Busch, Reinhardt and Shaffer (2009: 576-577) suggest that 'the greater legalisation of the multilateral trade regime poses asymmetric challenges for developing countries, perhaps allaying some concerns over the distribution of economic power, but raising new ones over the distribution of legal capacity'. Scholars have not agreed on this, and there are strong arguments which indicate that differences in relative power as well as institutional-legal capacities significantly affect performances in the WTO dispute settlement system. More recent studies such as Sattler and Bernauer (2011) have revised the importance of market power dynamics in relation to those of relative power and institutional-legal capacity in pairs of complainants-respondents.

Foreign trade, in its various dimensions, has frequently been used to provide a reference for comparing the performance of WTO members in the dispute settlement system. 
In a seminal study on the initiation of disputes in the period 1995-1998, Horn, Mavroidis and Nordstrom (1999) argued that the number of disputes in which countries become involved should be directly proportional to the number of deviations from WTO rules they face in their regular trade flows. In simpler terms, the higher the nominal value of trade of a country, the higher the number of irregularities that will occur in trade relations (both caused by the country itself and by others), and thus the higher the number of disputes in which the country will be involved (as complainant or respondent). In the absence of a convincing theoretical prediction of the number of irregular acts committed by other countries encountered by one member in its trade flow at any given time, the authors assume that deviations from WTO regulations occur with the same frequency, regardless of other factors related to the characteristics of a pair of exporting-importing countries and/ or industry. They demonstrate that the distribution of bilateral disputes fairly follow the defined baseline, depending directly on the volume of trade of members.

Holmes, Rollo and Young (2003), covering the period 1995-2002, and Bown (2005), studying the period 1995-2001, are the main scholars responsible for refining this approach, which was widely used in later studies. Their results indicate that in disputes involving non-targeted measures (negatively affecting many trading partners), export volume is positively correlated with the propensity to initiate a dispute or act as an interested party, and negatively with the propensity to act as free rider.

Francois, Horn and Kaunitz (2008) show that both the composition/diversity and volume of trade are important explanatory variables for country performances in WTO disputes. In an exporter-importer pairing, the higher the volume of exports in a particular economic sector from one country to another, the greater the number of expected trade disputes. In this regard, Sattler and Bernauer (2011) show that in a dynamic of bilateral relations between pairs of potential litigating countries, those with larger and more diversified economies and higher trade volumes are more likely to engage in trade disputes. The size of their markets makes them more attractive targets of litigation, because the potential gains are higher. In turn, their economic diversity and trade volumes also make it more likely that their own commercial interests will be affected. Relative power dynamics and differences in institutional-legal capacity play a lesser role in excluding countries from or reducing their access to the WTO dispute settlement system.

Copelovitch and Pevehouse $(2013,2014)$ show that other economic factors influencing foreign trade, especially exchange rate regimes, are also important determinants of trade disputes at the WTO. Drawing on data about all WTO members in the period 19952007, they conclude that countries with fixed exchange rates are more likely to initiate anti-dumping investigations, and also more likely to provoke disputes. However, this depends upon the level of openness of the capital account in their balance of payments, in line with the open economy model of Mundell-Fleming (Krugman and Obstfeld 2005). These findings indicate that the relationship between exchange rates and trade policy at the macro level reflected in the Mundell-Fleming model also play a role in the performance of countries in WTO disputes. Governments which sacrifice autonomous monetary policy by means of fixed exchange rates have stronger domestic political incentives 
for adopting more protectionist trade policies. The more protectionist countries are, the more likely they are to provoke a WTO dispute.

Kerner and Betz (2015) advanced the results of Copelovitch and Pevehouse (2013, 2014) arguing that governments in developing countries are more likely to initiate WTO disputes when overvalued real exchange rates place their exporters at a competitive disadvantage. This is an important indicator of the significance of trade dynamics, and therefore of any phenomena that can change these dynamics, on the performance of developing countries in the initiation of disputes at the WTO.

Jensen, Quin and Weymouth (2015) have examined the correlation between other factors affecting foreign trade, such as foreign direct investment, intra-firm trade, and exchange rate depreciation, with the propensity of US companies to file domestic anti-dumping investigation cases (trade remedies on the domestic and not the multilateral tier). They conclude that the variables which can modify the real dynamics of trade between countries are significant, and positively correlated with litigation.

The literature presented in this section does not use the particular data set or models used for this study. This raises the question or whether the use of a different data set and different models for analysing litigation by developing countries against the USA and the EU corroborates or moves away from those previous results in respect of institutionallegal capability, market power, and trade dynamics. The fourth section will attempt to answer this question. The following section will examine the WTO dispute settlement process in greater detail, and classify the results of completed disputes.

\section{The WTO dispute settlement process and the status of completed disputes}

According to the DSU (Art. 3), the overriding objective of the WTO's dispute settlement system is to facilitate negotiated settlements, in line with WTO agreements (WTO 2016a). In both stages of the dispute process, bilateral consultations and panel hearings (the litigation phase), members in conflict are encouraged to seek mutual understanding and/or request 'good offices, conciliation or mediation' from the WTO.

In the bilateral consultation stage, the complainant country presents a formal request for consultation to the alleged offender. According to the DSU (Art. 4), the complainant country should also notify the DSB as well as relevant WTO councils and committees (WTO 2016a). The main purpose of this phase is to seek a mutually acceptable solution to the damages suffered by the complainant. Therefore, it is a diplomatic phase, in line with the principle of 'good offices, conciliation and mediation'. It is also aimed at eliminating or reducing errors, and assessing the costs and benefits of pursuing the dispute. It has four possible outcomes: i) the complainant decides not to pursue the dispute, for unspecified reasons; ii) the parties reach a mutually agreed solution; iii) the respondent country corrects the contested policy; or iv) a panel is established.

This last-named step inaugurates the judicial stage of the dispute process. As noted previously, the panels report to the WTO's Dispute Settlement Body (DSB). Unless their 
findings are rejected by consensus, their findings become rulings of the DSB which the parties are obliged to accept. However, they can still come to a mutual agreement. Thus the search for understanding between the parties can occur even in highly conflictual situations (as in United States - Subsidies on Upland Cotton from Brazil (WT/DS267)). The panel phase has eight possible outcomes: i) mutual agreement; ii) the withdrawal or termination of the dispute; iii) the adoption of report(s) with recommendations to bring measure(s) into conformity; iv) implementation notified by the respondent; v) report(s) adopted with no further action required (if the respondent communicates to the DSB the correction of the policy under litigation, or that no inconsistences were found; vi) compliance proceedings completed with finding(s) of non-compliance; vii) compliance proceedings completed without finding(s) of non-compliance; and viii) authorisation to retaliate granted (where there is disagreement about the implementation).

Although parties are still able to reach a mutual agreement, this must occur before the adoption of the report(s) of the panel and/or of the Appellate Body. When the respondent modifies its policy prior to the adoption of the report(s) of the panel or of the Appellate Body, the dispute is classified as terminated or withdrawn (as in United States - Measures Affecting Imports of Woven Wool Shirts and Blouses from India (WT/DS33)). When the report(s) are adopted, and the respondent does not need to take any further action, the reports of the panel and the Appellate Body are approved by the DSB, and the case is resolved. It can mean that the respondent modified its policy (United States - Definitive Safeguard Measures on Imports of Certain Steel Products from China (WT/DS252)), or that the complainant country failed to prove that the policy under litigation was inconsistent (United States - Rules of Origin for Textiles and Apparel Products from India (WT/ DS243)).

The compliance panel assesses the adequacy of the implementation process in relation to the decisions of the panel and the Appellate Body. When it finds that compliance proceedings have been completed 'without a finding of non-compliance', it means that it has decided in favour of the respondent; in other words, the complainant did not demonstrate that the respondent failed or omitted to correct the policy under litigation (United States - Import Prohibition Measures of Certain Shrimp and Shrimp Products from Malaysia (WT/DS58)). Similarly, the compliance panel can find in favour of the complainant. When the panel's authority expires without any decision, it means that the complainant has not pursued the litigation further. Only one case in our data set ended in this way, and is interpreted as a favourable outcome for the respondent (United States - Anti-Dumping Measures on Oil Country Tubular Goods (OCTG) from Mexico (WT/DS282)).

Figure 1 presents the WTO dispute settlement system in graphic form. As such, it reflects all the possible outcomes of the complaints included in our dataset.

In the period under review, there were 43 complaints with favourable outcomes for developing countries. Eleven complaints were concluded during the consultation phase: nine were concluded via mutual agreements, and two were terminated. A total of $32 \mathrm{com}$ plaints were concluded during the panel phase. Of these, 14 were concluded with implementation notified by the respondent; nine in terms of agreements under article 3.6; three 
reports were adopted, with no further action required; three complaints were withdrawn; two were terminated; and in one instance, the authority of the panel expired.

Figure 1: The WTO's dispute settlement system
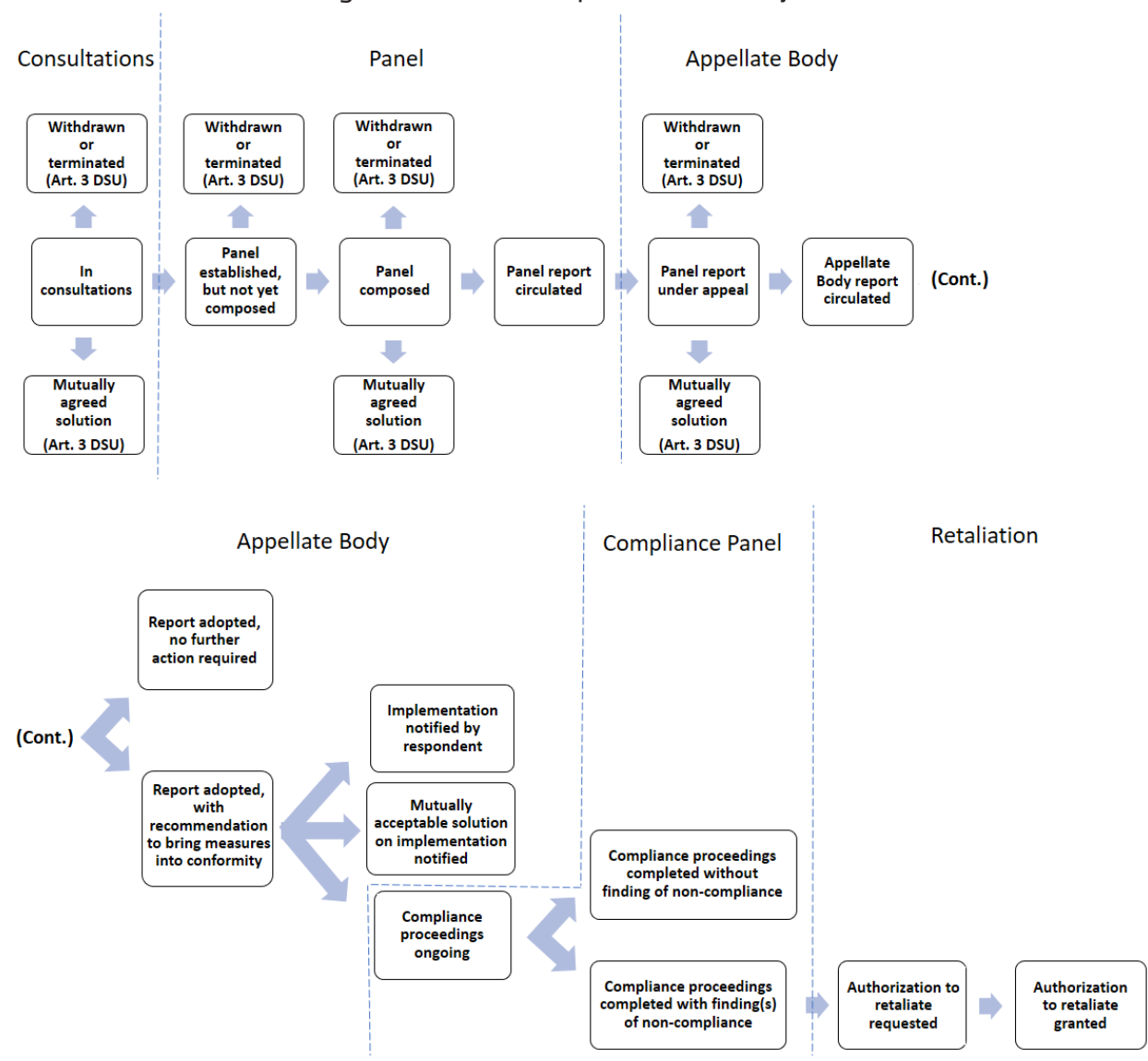

Source: Compiled by Edgard Vieira.

Seven complaints were concluded with unfavourable outcomes for developing countries. Five compliance proceedings were completed without findings of non-compliance, and two with findings of non-compliance.

The results of the completed complaints in our data set are classified according to each case report (WTO 2015), and in terms of the categories used in the WTO dispute settlement system (WTO 2016a).

\section{Models, analysis and results}

This section presents the results of our study. The data was processed with Generalised Linear Models (GLMs). Based on the literature, two different models, each with two subsets, were constructed to test the extent to which the relative power, institutional-legal 
capacity, trade profiles, and level of development of developing countries influence their performance at various stages of the WTO dispute settlement system.

STATS version 13.2 was used for the statistical calculations. Routine operations were based on GLM treatment patterns.

The models were as follows:

Model 1(a): The impact of institutional-legal capacity and power (GDP) on the initiation of disputes against the G2 by developing countries (dependent variable: INI)

Model 1(b): The impact of relative bilateral exports (EXP_G2) on the initiation of disputes against the G2 by developing countries (dependent variable: INI)

Model 2(a): The impact of relative exports to the rest of the world (EXP_World) on the success rate of disputes against the G2 by developing countries (dependent variable SUR)

Model 2(b): The impact of institutional-legal capability and power (GDP) on the successful completion of disputes against the G2 by developing countries (dependent variable: SUC)

Model 1 is aimed at estimating the annual effect of selected variables on the initiation of disputes by developing countries against the USA and EU from 1995 to 2012. It utilises longitudinal unbalanced panel data sets with data on dispute initiation and the explanatory variables for each country, processed year by year from their entry into the WTO. (In some instances, no data was available for some countries in certain years, and those entries were excluded from the model.)

Model 2 is aimed at estimating the effect of selected variables on the successful completion of disputes against the USA and EU in the period 1995-2012. This model utilises a cross-sectional design in which the value of each dependent variable (SUR or SUC) represents the role of the period from 1995 to 2012, and the value of the independent variables were period averages.

\section{Dependent variables}

The dependent variables were as follows:

INI: The number of disputes initiated annually by each developing country (count variable) - number of disputes initiated each year in the WTO by each developing country against the G2 in the period 1995-2012.

SUR: The success rate in the period for each developing country (continuous index variable) - number of positive results of each developing country on completed disputes in the WTO divided by the total number of disputes resolved by the same country in the period 1995-2012 for each developing country. 
SUC: The number of successes in the period for each developing country (count variable) - sum of the number of disputes completed in the WTO with positive results by each developing country against the G2 in the period 1995-2012.

It was not possible to use the same design for both models, due to the definition of each dependent variable: SUR and SUC are long-run performance measures and cannot be analysed in an annualised form, while INI is highly dependent on annual country data because it reflects the tendency to dispute initiation in each specific year in relation to the respective position of the other explanatory variables.

The dependent variable INI was treated using a GLM with Poisson distribution and a logarithmic link function. Models based on this distribution are used for non-linear data count with discrete distribution, that is, data which results from a count process (number of disputes initiated each year), and assume only integer values equal to or greater than zero.

The dependent variable SUC has the same specifications as INI because it also results from a count (the number of successes). In turn, the dependent variable SUR is represented by a continuous distribution index number in the range from zero to one (it can assume infinite values in this range), and was treated with normal distribution function and identity link function. Therefore, the treatment applied to SUR assumes that it is a random variable with normal distribution in the population, and that there is an average success rate in the population concentrating $95 \%$ of its density up to two standard deviations from the average.

\section{Independent variables}

The explanatory (independent) variables were incorporated in all three models, and were based on the relevant literature. The data sources were the World Bank database (2017) for GDP and level of development, and the World Integrated Trade Solution (WITS 2017) for international trade data.

In the case of the longitudinal Model 1, explanatory variables were used directly in their annual values for the period 1995-2012. In the case of the cross-sectional Model 2, explanatory variables were used considering period averages. All three models utilise a dummy variable representing differences of development among countries. As our dataset only reflected higher and lower middle-income developing countries, the variable HI was used to indicate income classification as high middle income for each year, or for the most of the period (depending on each model specification).

\section{Size of the economy (GDP)}

The size of the economy of each country was represented by its GDP. This can be understood as a measure of the relevance of the country as a potential market for foreign governments and companies, and the domestic industry's international competitiveness. The higher the aggregate supply of goods and services circulating in the economy (the higher 
the GDP), the greater the likelihood that domestic economic and commercial policies affect exporters or importer interests in the country and in other countries.

In addition, GDP is positively correlated with other variables such as education and technology (Nicholson 2005), representing two main effects: the extent of institutionallegal capacity, as well as market power. Therefore, a positive correlation between the dependent variables (INI, SUR and SUC) and GDP could be expected.

\section{Higher middle income (HI)}

A qualitative covariate (dummy) representing the higher middle income country group was used to centralise this as the focus group. This was aimed at capturing the differences between the average behaviour of higher and lower middle income countries.

\section{Foreign trade}

\section{a) Coefficient of bilateral trade openness (TRADE_G2)}

This variable was used to reflect the relative role of trade with the G2 in the economies of developing countries. This variable is calculated by dividing total trade with the G2 (exports plus imports) by GDP, known as the bilateral trade openness coefficient.

As in the case of the size of the economy, the greater the exposure of a country to trade flows with the G2, the greater the likelihood that its internal or external interests are affected by domestic or G2 trade policies. In other words, what really matters in the decision-making process is not so much the average effect of trade on the economy, but the intensity (relative volume) with which trade affects certain groups in the economy, which have greater capacity for and/or interest in mobilisation then a loose collection of other social actors.

However, order to separate the effect of trade with the G2 from GDP, the value of the first is used in relation to the latter (the coefficient of trade openness).

As in the case of GDP, TRADE_G2 can be expected to correlate positively with the dependent variables. The higher the coefficient of trade openness with the G2, the higher the number of disputes initiated, the number of successful disputes, and the dispute success rate.

\section{b) Relative bilateral exports (EXP_G2)}

An alternative hypothesis to TRADE_G2 was tested by relating bilateral exports to the G2 to GDP. The general argument remains the same, with one additional observation: this variable only captures exports and not the demand for imports from the G2. In this case, there is an implicit assumption that the performance of developing countries depend only on their exports to the G2 - in other words, that the interests of exporters prevail over those of importers and consumers in these countries. EXP_G2 can be expected to correlate positively with the dependent variables; the higher the participation of exports to the G2 in a country's GDP, the higher INI/SUR/SUC. 


\section{c) Relative bilateral preferential exports (PREF_G2)}

The threat of withdrawing preferential trade benefits is an important measure of the power of an actor to increase its net gains from trade. Unlike preferential trade arising from complementary economic agreements, free trade agreements, and regional integration processes, preferential trade obtained through independent, voluntary, and unilateral preferential trade schemes such as the Generalized System of Preferences (GSP) can become efficient drivers of power relations.

Most countries, even developing ones, offer some trade preferences to developing countries, especially least developed countries (LDCs). In addition to a regular GSP, the EU has adopted a specific GSP line for LDCs, the Everything but Arms arrangement (EBA), and the Cotonou Agreement (ACP). The USA, also in addition to the regular GSP and a specific line for LDC, has adopted the African Growth and Opportunity Act (AGOA) and the Caribbean Basin Initiative (CBI).

Therefore, this variable captures the flow of preferential trade that can be converted into a driver of power relations because of differences in relative power between the exporter-importer pair. As in the case of other trade variables, our interest lies in the extent of this effect in relation to GDP. PREF_G2 can be expected to have a negative effect on developing countries in that it inhibits the initiation of disputes as well as their success rate. That is, the greater the participation of preferential exports to the G2 in the economy, the lower INI/SUR/SUC will tend to be.

\section{d) Relative exports to the rest of the world (EXP_World)}

This variable is used to measure the average distributional effects of the export performance of countries, e.g. the combined share of other export markets (except the G2) in foreign trade. This variable is expressed in terms of exports to the rest of the world (except to the G2) relative to GDP. This allows us to put into perspective the economic importance of exports to the G2 for each country in relation to its overall trade performance. A negative effect between the dependent variables and EXP_WORLD is expected. The higher the participation of exports to the rest of the world in GDP, the lower the relative importance of exports to the G2, and therefore the lower INI/SUR/SUC will tend to be.

\section{Results}

Table 1 reflects the impact of institutional-legal capacity and power (GDP) as well as other selected factors on the initiation of disputes against the G2 by developing countries (Model 1(a)). It shows that the intercept (when the independent variable vector is equal to zero) and the variables GDP and PREF_G2 have a high statistical significance for the initiation of disputes in the WTO. The high intercept parameter result at -1,2276 indicates a high inertial restriction in the system which inhibits the initiation of disputes against the G2 by developing countries. In turn, developing countries need high levels of GDP (translating into high levels of institutional-legal capacity and market power) to enable them to initiate disputes against the G2. 
The need for greater capacity and power to act against the G2 is further enhanced in the face of the effect of preferential exports that have a negative effect of -7,7425. Although this is a marginal effect, it is statistically significant. TRADE_G2, EXP_World and HI are not significant in this model.

Table 1: Model 1(a): The impact of institutional-legal capacity and power (GDP) on the initiation of disputes against the G2 by developing countries (INI)

\begin{tabular}{lllllllll}
\hline Parameter & Estimate & $\begin{array}{l}\text { Standard } \\
\text { Error }\end{array}$ & \multicolumn{2}{l}{$\begin{array}{l}\text { Wald 95\% } \\
\text { Confidence Limits }\end{array}$} & $\begin{array}{l}\text { Likelihood 95\% } \\
\text { Confidence Limits }\end{array}$ & $\begin{array}{l}\text { Wald } \\
\text { Ch-Square }\end{array}$ & Pr > ChiSq \\
\hline Intercept & $-1,1276$ & 0,2300 & $-1,5784$ & $-0,676$ & $-1,5941$ & $-0,6908$ & 24,04 & $<0,0001$ \\
GDP & 0,6645 & 0,0948 & 0,4787 & 0,8503 & 0,4724 & 0,8464 & 49,14 & $<0,0001$ \\
TRADE_G2 & 2,2405 & 1,3258 & $-0,3581$ & 4,8391 & $-0,4035$ & 4,7969 & 2,86 & 0,0910 \\
PREF_G2 & $-7,7425$ & 2,0273 & $-11,716$ & $-3,769$ & $-11,8545$ & $-3,9589$ & 14,59 & 0,0001 \\
EXP_World & 1,2658 & 0,9360 & $-0,5689$ & 3,1004 & $-0,6214$ & 3,0763 & 1,83 & 0,1763 \\
HI 0 & 0,2969 & 0,1876 & $-0,0708$ & 0,6646 & $-0,0675$ & 0,6699 & 2,50 & 0,1135 \\
HI 1 & 0 & 0 & 0 & 0 & 0 & 0 & $\ldots$ & $\ldots$ \\
\hline
\end{tabular}

Source: Compiled by Carlos Canesin.

In general, considering a logarithmic relationship in the Poisson distribution of INI, developing countries start with a constraint of -0,32 (Intercept) disputes initiated against the G2, and every trillion dollars in GDP (at constant 2005 prices) adds $+1,94$ disputes against the G2. In turn, for every $1 \%$ of participation of bilateral preferential exports in GDP, 0,00043 fewer disputes are initiated. This last effect is very small, but consistent. The differences in income level among developing countries (higher middle income versus lower middle income) do not affect their performance in terms of initiating disputes against the G2.

In Table 2, TRADE_G2 is replaced with relative bilateral exports (EXP_G2). It confirms that exports are the only significant dimension determining the behaviour of developing countries in disputes against the G2. EXP_G2 is statistically significant and have a high impact on INI; for every $1 \%$ in participation of bilateral exports to the G2 in GDP, some 0,67 disputes are added to the total.

Table 2: Model 1(b) - the impact of relative bilateral exports (EXP_G2) on the initiation of disputes against the G2 by developing countries (INI)

\begin{tabular}{lllllllll}
\hline Parameter & Estimate & $\begin{array}{l}\text { Standard } \\
\text { Error }\end{array}$ & \multicolumn{2}{l}{$\begin{array}{l}\text { Wald 95\% } \\
\text { Confidence Limits }\end{array}$} & $\begin{array}{l}\text { Likelihood 95\% } \\
\text { Confidence Limits }\end{array}$ & $\begin{array}{l}\text { Wald } \\
\text { Chi-Square }\end{array}$ & Pr > ChiSq \\
\hline Intercept & $-1,0939$ & 0,2156 & $-1,5165$ & $-0,671$ & $-1,5318$ & $-0,6853$ & 25,74 & $<0,0001$ \\
GDP & 0,6520 & 0,0902 & 0,4751 & 0,8289 & 0,4673 & 0,8237 & 52,19 & $<0,0001$ \\
EXP_G2 & 4,1907 & 1,7564 & 0,7482 & 7,6333 & 0,6168 & 7,5146 & 5,69 & 0,0170 \\
PREF_G2 & $-8,1722$ & 1,9930 & $-12,0784$ & $-4,266$ & $-12,2905$ & $-4,5201$ & 16,81 & $<0,0001$ \\
EXP_World & 1,2337 & 0,9413 & $-0,6112$ & 3,0787 & $-0,6620$ & 3,0526 & 1,72 & 0,1900 \\
HI 0 & 0,3002 & 0,1877 & $-0,0677$ & 0,6681 & $-0,0644$ & 0,6734 & 2,56 & 0,1098 \\
HI 1 & 0 & 0 & 0 & 0 & 0 & 0 & $\ldots$ & $\ldots$ \\
\hline
\end{tabular}

Source: Compiled by Carlos Canesin. 
The results for the other explanatory variables are similar to Table 1 . There is an inertial system restriction (Intercept) of - 0,33 disputes; every trillion dollars of GDP adds 1,92 disputes to the total initiated; and every $1 \%$ of relative preferential export participation in GDP reduces the number of disputes by $-0,00028$. Relative exports to the rest of the world and differences in income levels had no observable effects.

Table 3 reflects the impact of the explanatory variables on the successful completion of disputes against the G2 (Model 2(a)). In this case, there are only two statistically significant parameters: the intercept, and relative exports to the rest of the world (EXP_ WORLD). Differences in income levels have no discernible impact on the results.

Table 3: Model 2(a) - The impact of relative exports to the rest of the world (EXP_World) on the success rate of disputes against the G2 by developing countries (SUR)

\begin{tabular}{lllllllll}
\hline Parameter & Estimate & $\begin{array}{l}\text { Standard } \\
\text { Error }\end{array}$ & \multicolumn{2}{l}{$\begin{array}{l}\text { Wald 95\% } \\
\text { Confidence Limits }\end{array}$} & $\begin{array}{l}\text { Likelihood 95\% } \\
\text { Confidence Limits }\end{array}$ & $\begin{array}{l}\text { Wald } \\
\text { Chi-Square }\end{array}$ & Pr > ChiSq \\
\hline Intercept & 1,1203 & 0,0502 & 1,0220 & 1,2187 & 1,0162 & 1,2245 & 498,2 & $<0,0001$ \\
GDP & $-0,0267$ & 0,0266 & 0,0788 & 0,0254 & $-0,0819$ & 0,0285 & 1,01 & 0,3151 \\
EXP_G2 & 0,0661 & 0,4669 & $-0,8490$ & 0,9812 & $-0,9032$ & 1,0354 & 0,02 & 0,8874 \\
PREF_G2 & $-0,0145$ & 0,2453 & $-0,4953$ & 0,4662 & $-0,5238$ & 0,4947 & 0 & 0,9528 \\
EXP_World & $-1,6213$ & 0,1540 & $-1,9232$ & $-1,319$ & $-1,9411$ & $-1,3016$ & 110,80 & $<0,0001$ \\
HI 0 & 0,0217 & 0,0413 & $-0,0592$ & 0,1026 & $-0,0640$ & 0,1074 & 0,28 & 0,5991 \\
HI 1 & 0 & 0 & 0 & 0 & 0 & 0 & $\ldots$ & $\ldots$ \\
\hline \multicolumn{7}{c}{ Source: Compiled by Carlos Canesin. }
\end{tabular}

Table 3 reflects a linear relationship between the dependent and independent variables. The intercept shows a higher than $100 \%(1,12)$ success rate regardless of other explanatory variables. This indicates that once a country has overcome the barriers to initiating disputes against the G2 (Model 1), it is virtually certain to win the dispute.

This result confirms the proposition in the literature that developing countries only tend to initiate disputes after careful cost-benefit analyses, and only when the probability of success is very high. This performance is only affected by the participation of exports to the rest of the world in GDP (EXP_World). Although EXP_World has no effect on the initiation of disputes (Model 1), it has a negative effect on the success rate. Every $1 \%$ increase in the participation of exports to the rest of the world in GDP reduces the success rate by 0,016 .

This phenomenon can be explained by the fact that the success rate is the average of a longer period in which the country concerned constantly reviews the cost and benefits of maintaining disputes in the WTO. Therefore, the importance of individual disputes in the face of the country's broader commercial interests (exports to the rest of the world) can be revised in the longer term. As a result, it may choose not to make an effort to pursue demands that have become less important in relation to its overall export performance. In the initiation phase (Model 1), this variable has no effect because countries look only to the terms of their direct trade relationship with the G2 at the moment when they initiate a dispute. 
Table 4 reflects the impact of institutional-legal capability and power (GDP) on the successful completion of disputes against the G2 (Model 2(b)). It refutes the existence of a non-zero intercept on the regression curve. Therefore, the inertial amount of the successes count (the value of the vector of independent variables) is strictly zero.

Table 4: Model 2(b) - The impact of institutional-legal capability and power (GDP) on the successful completion of disputes against the G2 by developing countries (SUC)

\begin{tabular}{lllllllll}
\hline Parameter & Estimate & $\begin{array}{l}\text { Stan- } \\
\text { dard } \\
\text { Error }\end{array}$ & $\begin{array}{l}\text { Wald 95\% Confi- } \\
\text { dence Limits }\end{array}$ & $\begin{array}{l}\text { Likelihood 95\% } \\
\text { Confidence Limits }\end{array}$ & $\begin{array}{l}\text { Wald Chi- } \\
- \text { Square }\end{array}$ & Pr > ChiSq \\
\hline Intercept & 0 & 0 & 0 & 0 & 0 & 0 & $\ldots$ & $\ldots$ \\
GDP & 0,5255 & 0,2180 & 0,0983 & 0,9527 & 0,0561 & 0,9359 & 5,81 & 0,0159 \\
EXP_G2 & 6,4609 & 3,9568 & $-1,2944$ & 14,216 & $-1,2285$ & 14,5524 & 2,67 & 0,1025 \\
PREF_G2 & $-2,5935$ & 2,7909 & $-8,0636$ & 2,8766 & $-8,9148$ & 2,2998 & 0,86 & 0,3527 \\
EXP_World & $-6,1224$ & 3,1132 & $-12,2242$ & $-0,021$ & $-13,2596$ & $-0,9382$ & 3,87 & 0,0492 \\
HI 0 & 0,9737 & 0,5041 & $-0,0144$ & 1,9618 & $-0,0448$ & 1,9430 & 3,73 & 0,0534 \\
HI 1 & 0,6164 & 0,5219 & $-0,4064$ & 1,6392 & $-0,5137$ & 1,5633 & 1,40 & 0,2375 \\
\hline
\end{tabular}

Source: Compiled by Carlos Canesin.

Although Model 2(a) shows a tendency nearly equal to identity (one dispute initiated equals one success obtained) for transforming disputes initiated into successes (the Model 2 (a) Intercept is $+1,12$ ), the real count of the absolute number of successes obtained starts at zero (the Model 2(b) Intercept is zero). These results are complementary and make perfect sense, both from a theoretical and practical point of view. In Model 2 there is no systemic restriction on the initiation of disputes, as in Model 1. Once a country has overcome the negative systemic restrictions on initiating disputes against the G2 (Model 1), the results are not affected by this same restriction (Model 2).

In line with these results, the absolute number of successes achieved by developing countries against the G2 depends on their institutional-legal capacity and power, as reflected by their respective GDP. This is the only variable with a high statistical significance in Model 2(b). The overall statistical significance of the coefficients of other explanatory variables was discarded. Despite the fact that the effect of PREF_G2 did not reach the 5\% probability threshold for being refuted $(0,0492)$, Model 2 (b) is effective in determining only the negative direction of the PREF_G2 effect within the confidence interval. The actual size of this effect is uncertain, and has no significant impact on the result.

Therefore, we can say that the number of successes achieved by developing countries in disputes against the USA and EU in the WTO depends directly on the absolute size of their GDP, which includes the dimensions of capability and power. Every trillion dollars of GDP adds 1,69 to the absolute number of successes. In turn, the participation of exports to the rest of the world in GDP tends to decrease the allocation of capacity and power to those disputes, given their relative lack of importance for the overall export performance of those countries in the long run. 
Even though the latter relationship has a negative direction which is well defined in Model 2(b), its final effect is uncertain, and statistically negligible. Therefore, GDP alone is a good predictor of the absolute number of disputes completed successfully by developing countries against the G2.

These combined results show that the participation of bilateral trade with the USA and EU in the GDP (relative bilateral exports) of developing countries is a major factor in initiating disputes in the WTO against the G2. However, their capacity and power (as represented by GDP) remains the most relevant explanatory variable, and play a vital role in determining the number of disputes resolved in favour of developing countries.

\section{Conclusion}

The literature identifies the rules and norms of the DSU as well as the institutional-legal capacity, market power, and trade profile of developing countries as potential determinants of their performances in WTO disputes against the G2. This study shows that institutional-legal capacity and market power are the most significant factors constraining the initiation of disputes against the G2. This remains the case regardless of the influence of other factors, such as trade profiles, on the dispute initiation phase. It also shows that the likelihood of disputes being initiated against the G2 is not determined by absolute or nominal trade flows (total trade) with the G2, but by the extent of bilateral export participation in GDP.

Another important set of results relates to the successful completion of disputes in the litigation phase. First, once a developing country has declared a dispute, it is virtually certain to win. This finding strengthens the dominant position in the literature which argues that developing countries only initiate disputes after a careful cost-benefit analysis, and only when they are highly likely to succeed. Second, institutional-legal capacity and market power (measured in terms of GDP) are once again the key determinants of the number of successes achieved in disputes against the G2. Thirdly, as regards trade factors, the success rate is only affected (negatively) by the relative importance of countries' longterm export performance to world markets in relation to exports to the G2. The success rate is not affected by GDP.

This result supports the claims in the literature that developing countries only initiate which they have a high probability of winning. In addition, this study shows that the only factor that is statistically significant in diminishing the probability of victory is EXP_World - the continuous re-evaluation of the cost-benefit of maintaining each specific dispute in face of its relative importance compared to the overall export performance of the country in the long run.

Levels of development measured in terms of GNP per capita (the World Bank method) do not affect the number of disputes initiated, the number of successes achieved, or the success rate. The major explanatory variable for both the initiation of disputes and the number of successful disputes is the size of the economy (GDP), as a proxy for institutional-legal capacity and market power. 


\section{Notes}

1 The European Union is a regional bloc of 27 countries, with a common market and common commercial policies. Since 1 December 2009 its official name in the WTO is the European Union. Previously, it was known as the European Community (EC).

\section{References}

Advisory Centre on WTO Law (ACWL). 2016. The ACWL's Mission. At http://www.acwl.ch/ acwl-mission/ [Accessed on 10 March 2016].

Betz, Timm and Andrew Kerner. 2016. 'Real exchange rate overvaluation and WTO dispute initiation in developing countries'. International Organization 70 (4): 797-821.

Bown, Chad P. 2005. 'Participation in WTO dispute settlement: complainants, interested parties, and free riders'. World Bank Economic Review 19 (2): 287-310.

Bown, Chad P and Rachel McCulloch. 2010. 'Developing countries, dispute settlement, and the Advisory Centre on WTO Law'. Journal of International Trade and Economic Development 19 (1): 33-63.

Blonigen, Bruce A and Chad P Bown. 2003. 'Anti-dumping and retaliation threats'. Journal of International Economy 60 (2): 249-273.

Busch, Marc L, Eric Reinhardt and Gregory C Shaffer. 2008. 'Does legal capacity matter? Explaining dispute initiation and antidumping actions in the WTO'. International Centre for Trade and Sustainable Development (ICTSD) Project on Dispute Settlement, Issue Paper No 4. At http://www.ictsd. org/sites/default/files/research/legal_capacity1.pdf [Accessed on 13 July 2017]. 559-77.

2009. 'Does legal capacity matter? A survey of WTO Members'. World Trade Review 8 (4):

Copelovitch, Mark S and John C Pevehouse. 2013. 'Ties that bind? Preferential trade agreements and exchange rate policy choice.' International Studies Quarterly 57 (2): 385-399.

2014. 'The trilemma and trade policy: exchange rates, financial openness, and WTO disputes'. Version of a paper presented at the 5th Annual Conference on the Political Economy of International Organizations, Villanova University, January 2012; and at the 5th Annual Meeting of the International Political Economy Society, Harvard University, November 2010. University of Wisconsin, Madison. At http://personal.lse.ac.uk/RICKARD/markc.pdf [Accessed on 12 June 2016].

Davis, Christina L. 2006. 'Do WTO rules create a level playing field? The experience of Peru and Vietnam. In John Odell (ed), Negotiating Trade: Developing Countries in the WTO and Nafta. Cambridge: Cambridge University Press, pp. 219-256.

François, Joseph, Henrick Horn and Nikolas Kaunitz. 2008. 'Trading profiles and developing countries participation in the WTO Dispute Settlement System'. Research Institute of Industrial Economics (IFN). At http://hdl.handle.net/10419/81296 [Accessed on 3 April 2014].

Guzman, Andrew and Beth Simmons. 2005. 'Power plays and capacity constraints: the selection of defendants in WTO disputes'. Journal of Legal Studies 34 (2): 557-598.

Habka, Bruna D. 2013. O Caso do Algodão na OMC: A Parceria entre Governo e Empresários. Curitiba: Appris. 
Holmes, Peter, Jim Rollo and Alasdair R Young. 2003. 'Emerging trends in WTO dispute settlement: back to the GATT?' World Bank Policy Research Working Paper 3133. At http://documents.worldbank.org/curated/pt/560521468763780021/pdf/multi0page.pdf [Accessed on 31 January 2016].

Horn, Henrik, Petros C Mavroidis and Håkan Nordström. 1999. 'Is the use of the WTO dispute settlement system biased?' CEPR Discussion Paper Series n. 2340. At http://econ-law.se/Papers/ Disputes000117.pdf [Accessed on 31 January 2016].

Jackson, John H. 2006. The World Trading System: Law and Policy of International Economic Relations. Cambridge: MIT Press.

2008. 'The case of the world trade system'. International Affairs 84 (3): 437-454.

Jensen, Bradford J, Dennis P Quinn and Stephen Weymouth. 2015. 'The Influence of foreign direct investments, intra firm trading, and currency undervaluation on US firm trade disputes'. International Organization 69 (4): 913-947.

Krugman, Paul R and Maurice Obstfeld. 2005. Economia Internacional: Teoria e Prática. São Paulo: Pearson Addison Wesley.

Liyu, Han and Henry Gao. 2011. 'China's experience in utilizing the WTO dispute settlement mechanism'. In Gregory Shaffer and Ricardo Melendez-Ortiz (eds), Dispute Settlement at the WTO: The Developing Country Experience. Cambridge: Cambridge University Press, pp. 174-209.

Smith, James McCall. 2006. 'Compliance bargaining in the WTO: Ecuador and the bananas dispute'. In John Odell (ed), Negotiating Trade: Developing Countries in the WTO and NAFTA. Cambridge: Cambridge University Press, pp. 257-288.

Statistical Analysis System (STATS). 2016. Analytics software. At https://odamid.oda.sas.com/ [Accessed on 13 July 2017].

World Integrated Trade Solution (WITS). 2017. Software application and database to generate trade statistics. At http://wits.worldbank.org/Default.aspx [Accessed on 2 February 2017].

World Bank. 2017. 'World Bank Open Data'. At http://data.worldbank.org/ [Accessed on 31 January 2017].

World Trade Organization (WTO). 2015. 'Dispute Settlement'. At https://www.wto.org/english/ tratop_e/dispu_e/dispu_by_country_e.htm [Accessed on 30 August 2015].

. 2016a [1994]. 'Understanding on Rules and Procedures Governing the Settlement of Dis-

putes' (Dispute Settlement Understanding - DSU). At https://www.wto.org/english/docs_e/legal_e/28-dsu_e.htm [Accessed on 15 September 2016].

.2016b. 'Current status of disputes'. At https://www.wto.org/english/tratop_e/dispu_e/dispu_ current_status_e.htm [Accessed on 20 September 2016].

. 2016c. 'Dispute Settlement Body'. At https://www.wto.org/english/tratop_e/dispu_e/dispu_ body_e.htm [Accessed on 25 September 2016].

\section{Acknowledgments}

This article benefited from CNPq's support through the authors' Research Productivity Grant and from the excellent work done by Edgard Carneiro Vieira (former undergraduate student in International Relations at the University of Brasília) on the foreign trade databases used in the Models and in Picture 1. We are also grateful to the valuable comments of two anonymous reviewers. The responsibility of the text, as customary, is of the authors. 


\title{
About the authors
}

Maria Izabel V de Carvalho has her PhD in Political Sciences by the University of São Paulo. She has a Postdoctoral fellowship in the Centre for International Studies, London School of Economics and Political Science. She is Senior Associate Researcher in the Institute of International Relations of the University of Brasilia. She has published various articles in journals, such as: Dados - Revista de Ciências Sociais, Revista Brasileira de Política Internacional, e Contexto Internacional. Coeditor: O Século XXI no Brasil e no Mundo. Democracy and Foreign Policy, Developing Countries and Multilateral Trade Negotiations, and Rules and Power in the Multilateral Trade Regime are her interest areas.

Carlos Henrique Canesin is $\mathrm{PhD}$ in International Relations (IREL - University of Brasilia). He was tenured assistant professor at the Faculty of Law and International Relations of the Federal University of Grande Dourados; and served at the Brazilian Embassy in Washington DC assisting on bilateral and multilateral trade themes and trade remedies. Currently he researches in the fields of trade and international cooperation/development/ integration; is programme manager for international cooperation (south-south/ODA and $R \& D$ ) with Southern and Eastern Africa, and Central America and the Caribbean at the Brazilian Agricultural Research Corporation (Embrapa); and is professor of international relations at the University Center of Brasilia (UniCEUB). He has academic and professional experience in political economy, trade, cooperation, development, project/ programme management and international negotiations.

\section{O Papel da Capacidade e Poder Institucional- Legal para Explicar a Performance dos Países em Desenvolvimento nas Disputas na OMC contra o $\mathrm{G}_{2}$}

\begin{abstract}
Resumo: Neste artigo, é analisada a performance de membros em desenvolvimento em disputas iniciadas contra os Estados Unidos e a UE (G2) nas disputas de controvérsias da OMC entre 1995 e 2012. É investigada a influência das regras da OMC, capacidade legal, poder de mercado, e dinâmicas de comércio em duas amostras: as disputas iniciadas e concluídas contra o G2. A abordagem dos Modelos Lineares Generalizados (MLG) é adotada para analisar os dados. Conclui-se que o perfil das exportações dos países para o G2 é importante para determinar o processo de iniciação das disputas. Contudo, os fatores de poder de mercado e capacidade legal institucional (GDP) permanecem como os aspectos mais relevantes quando se trata da iniciação de disputas, bem como são especialmente influenciadores na determinação do número de disputas vitoriosas contra o G2.
\end{abstract}


Palavras-chave: Países em desenvolvimento e as disputas de controvérsias da OMC; Poder de mercado; Regras e procedimentos das disputas de controvérsias da OMC; Modelos Lineares Generalizados; Capacidade legal institucional

Received on 21 April 2017, and approved for publication on 25 July 2017.

\section{(cc) BY-NC https://creativecommons.org/licenses/by-nc/4.0/}

